\title{
Penerapan Model Pembelajaran Aktif Course Review Horay (CRH) untuk Meningkatkan Prestasi Belajar Matematika
}

\author{
Winadi \\ SMP Negeri 2 Tawangsari \\ Email: winadi_w@yahoo.co.id
}

\begin{abstract}
Abstrak
Tujuan penelitian tindakan kelas ini adalah untuk meningkatkan prestasi belajar Matematika siswa melalui model pembelajaran aktif CRH pada siswa kelas VIII F semester I SMP Negeri 2 Tawangsari tahun pelajaran 2018/ 2019. Penelitian ini dilaksanakan pada bulan Juli sampai November 2018 di SMP Negeri 2 Tawangsari. Subjek penelitian ini adalah siswa kelas VIII F sebanyak 32 siswa. Penelitian Tindakan Kelas ini dilakukan dalam dua siklus. Teknik pengumpulan data menggunakan teknik dokumentasi, observasi, dan tes tertulis. Alat pengumpulan data berupa lembar pengamatan, butir soal tes, dan dokumen daftar nilai. Analisis data menggunakan analisis deskriptif komparatif yang dilanjutkan refleksi. Setiap siklus terdiri dari empat langkah, yaitu: (1) Perencanaan, (2) Pelaksanaan Tindakan, (3) pengamatan, dan (4) Refleksi. Hasil penelitian menunjukkan adanya peningkatan prestasi belajar Matematika siswa, nilai rata-rata prestasi belajar Matematika siswa mengalami peningkatan yaitu sebelum tindakan sebesar 65,8, pada siklus I sebesar 72,9 dan pada siklus II sebesar 80,9. Selain itu, persentase ketuntasan belajar siswa juga meningkat, yaitu sebelum tindakan sebesar 48,8\%, siklus I sebesar $62,5 \%$ dan siklus II sebesar 90,6\%. Sehingga dapat disimpulkan bahwa "Model pembelajaran aktif CRH dapat meningkatkan prestasi belajar Matematika siswa kelas VIII F semester I SMP Negeri 2 Tawangsari tahun pelajaran 2018/ 2019".
\end{abstract}

Kata kunci: Prestasi Belajar Matematika, Model Pembelajaran Aktif CRH

\section{The Application of Active Learning Course Review Horay (CRH) to Improve the Achievement of Mathematics}

\author{
Winadi \\ SMP Negeri 2 Tawangsari \\ Email: winadi_w@yahoo.co.id
}

\begin{abstract}
The purpose of this classroom action research is to improve students' learning achievement of Mathematics through active learning model of CRH in grade VIII F students of semester I of SMP Negeri 2 Tawangsari in the 2018/2019 school year. This research was conducted from July to November 2018 in SMP Negeri 2 Tawangsari. The subjects of this study were students of class VIII F as many as 32 students. This research is a Classroom Action Research conducted in two cycles. Data collection techniques used documentation, observation, and written tests. Data collection tools are observation sheets, test items, and value list documents. Data analysis using comparative descriptive analysis followed by reflection on each cycle consists of four steps, namely: (1) Planning, (2) Action Implementation, (3) observation, and (4) reflection. The results of this study indicate an increase in learning achievement of Mathematicsstudents. This can be seen from the average score of learning achievement of Mathematics students also experienced an increase before the action of 65,8, in the first cycle of 72,9 and on the second cycle of 80,9. In addition, the percentage of students' learning mastery, example before the action of 48,8\%, in the first cycle of 62,5\% and in the second cycle of 90,6\%. So it can be concluded that "Active learning model of CRH can improve the learning achievement of Mathematicsstudents of class VIII F semester I SMP Negeri 2 Tawangsari 2018/2019 academic year". Keywords: Learning Achievement of Craft Subjects, Active Learning Model of CRH
\end{abstract}

\section{PENDAHULUAN}


Pelajaran Matematika diberikan kepada jenjang pendidikan SMP pada kurikulum 2013. Banyak guru yang menyadari bahwa Matematika dianggap sebagai pelajaran yang membosankan oleh sebagian besar siswa. Sehingga banyak siswa yang mengeluh tentang kesulitan belajar dalam mengikuti pembelajaran Matematika. Dari hasil pengamatan, nilai rata-rata ulangan harian siswa dalam belajar Matematika masih rendah yaitu belum mencapai KKM. Hal ini dibuktikan dengan nilai yang didapat siswa kelas VIII F SMP Negeri 2 Tawangsari mendapat nilai dibawah 71 (KKM).

Kesulitan ini sering kita jumpai pada saat proses KBM berlangsung, rendahnya prestasi belajar siswa karena kurangnya semangat belajar siswa. Dalam satu kelas terdapat beberapa siswa yang merespon, menyerap dan bahkan mengerjakan soal - soal latihan. Salah satu penyebabnya adalah cara penyajian belajar dan suasana pembelajaran yang kurang menarik dan menyenangkan.

Guru kurang kreatif dan inovatif dalam menyampaikan pelajaran, dimana guru masih menggunakan metode ceramah dan kurang melibatkan siswa sehingga siswa menjadi cepat bosan bahkan terkadang siswa hanya duduk, diam, dan tidak ada gagasan atau ide yang ingin diucapkan. Padahal sering kali dalam proses pembelajaran adanya kecenderungan siswa tidak bertanya pada guru meskipun sebenarnya siswa belum mengerti materi yang sedang diajarkan. Hal ini berakibat pada hasil belajar Matematika siswa.

Berdasarkan hasil pengamatan peneliti selaku guru Matematika kelas VIII F SMP Negeri 2 Tawangsari, masalah yang dihadapi oleh siswa sejauh ini adalah kurangnya keaktifan dan rendahnya prestasi belajar siswa, salah satunya adalah materi Koordinat Kartesius. Karena pada bab ini siswa harus bisa menunjukkan dan menggambar pada bidang kartesius. Hal ini dapat dilihat dari kegiatan belajar mengajar di kelas VIII F dengan KKM 71, nilai rata-rata hasil ulangan harian Matematika materi Koordinat Kartesius di kelas tersebut yaitu 65,8 dengan persentase ketuntasan sebesar 48,8\%. Selain itu, pada kegiatan pembelajaran di dalam kelas siswa hanya bersikap pasif, sedangkan yang aktif adalah guru. Sehingga siswa merasa bosan dan kurang termotivasi dalam belajar Matematika . 
Untuk itu guru diharapkan dapat menciptakan suasana kelas yang menyenangkan sehingga siswa dapat termotivasi dalam belajar Matematika dan dapat menambah keaktifan siswa dalam pembelajaran. Kurangnya suasana kelas yang menyenangkan dan perlu adanya suatu model pembelajaran yang inovatif dan kreatif yang dapat menumbuhkan semangat belajar Matematika dan memperkuat daya ingat siswa terhadap materi yang dipelajari sehingga dapat menunjang terciptanya kegiatan belajar mengajar yang kondusif.

Upaya untuk meningkatkan prestasi belajar Matematika siswa adalah dengan menggunakan model pembelajaran yang menarik minat belajar siswa. Untuk itu peneliti menerapkaan model pembelajaran aktif tipe Course Review Horay (CRH) yaitu model pembelajaran yang dapat menciptakan suasana kelas menjadi meriah dan menyenangkan karena setiap kelompok yang dapat menjawab benar maka siswa tersebut diwajibkan berteriak "HORE" atau yel-yel lainnya yang disukai. Course Review Horay adalah salah satu model pembelajaran yang mendorong siswa untuk ikut aktif dalam belajar. Dengan model pembelajaran Course Review Horay diharapkan dapat melatih kerja sama dalam menyelesaikan masalah dengan pembentukan kelompok, pembelajarannya menarik, dan mendorong siswa untuk terjun kedalamnya, tidak monoton karena diselingi sedikit hiburan sehingga suasana tidak menegangkan serta siswa lebih semangat belajar karena suasana pembelajaran berlangsung menyenangkan sehingga mampu membantu siswa dalam meraih nilai yang tinggi.

Menurut Widodo (http://pustaka.pandani.web.id/2013/10/model-pembelajarankooperatif-tipe.html diakses tanggal 12 November 2017 pukul 16.00 WIB), model pembelajaran aktif tipe Course Review Horay yaitu model pembelajaran yang dapat menciptakan suasana kelas menjadi meriah dan menyenangkan karena setiap kelompok yang dapat menjawab benar maka siswa tersebut diwajibkan berteriak "HOREY" atau yel-yel lainnya yang disukai. Course Review Horay adalah salah satu model pembelajaran yang mendorong siswa untuk ikut aktif dalam belajar. Dengan model pembelajaran Course Review Horay diharapkan dapat melatih kerja sama dalam menyelesaikan masalah dengan pembentukan kelompok, pembelajarannya menarik dan 
mendorong siswa untuk terjun kedalamnya, tidak monoton karena diselingi sedikit hiburan sehingga suasana tidak menegangkan serta siswa lebih semangat belajar karena suasana pembelajaran berlangsung menyenangkan sehingga mampu membantu siswa dalam meraih nilai yang tinggi.

Menurut Widodo (http://pustaka.pandani.web.id/2013/10/model-pembelajarankooperatif-tipe.html diakses tanggal 12 November 2017 pukul 16.00 WIB) langkahlangkah penerapan model pembelajaran aktif Course Review Horay adalah sebagai berikut: (1) Guru menyampaikan kompetensi yang ingin dicapai, kompetensi ini disampaikan agar pembelajaran lebih terarah tujuannya; (2) Guru mendemonstrasikan atau menyajikan materi sesuai topik bahasan yang sedang diajarkan; (3) Untuk menguji pemahaman, siswa disuruh membuat tempat jawaban. Tempat jawaban disini berbentuk tabel (kotak) yang berisi sembilan tempat, enam belas kotak ataupun dua puluh lima kotak. Banyaknya kotak tempat jawaban disesuaikan dengan kebutuhan dan tiap kotak jawaban diisi angka sesuai dengan selera masing-masing siswa; (4) Guru membaca soal secara acak sesuai dengan nomor yang telah disiapkan sebelumnya. Siswa menulis jawaban di dalam kotak yang nomornya disebutkan guru. Soal yang telah dibacakan langsung didiskusikan, kalau benar diisi tanda benar $(\sqrt{ })$ dan salah diisi tanda silang $(X)$. Disini dibutuhkan kejujuran dari siswa yang telah menjawab salah ataupun benar; (5) Siswa yang sudah mendapat tanda $(\sqrt{ })$ secara vertikal atau horizontal, atau diagonal harus segera berteriak horay atau yel-yel lainnya; (6) Nilai siswa dihitung dari jawaban benar dan jumlah horay yang diperoleh; (7) Penutup pembahasan. Penutup dari pembahasan ini dapat berupa penyimpulan dari guru ataupun disimpulkan sendiri oleh siswa.

Berdasarkan uraian di atas, dapat dirumuskan permasalahan sebagai berikut: "Apakah model pembelajaran aktif CRH dapat meningkatkan prestasi belajar Matematika siswa kelas VIII F semester I SMP Negeri 2 Tawangsari tahun pelajaran 2018/ 2019?”. Tujuan penelitian ini adalah untuk meningkatkan prestasi belajar Matematika dengan menerapkan pembelajaran aktif CRH pada siswa kelas VIII F semester I SMP Negeri 2 Tawangsari tahun pelajaran 2018/ 2019. Prestasi belajar Matematika dibatasi pada materi Koordinat Kartesius pada aspek pengetahuan. 


\section{METODE}

Penelitian ini adalah Penelitian Tindakan Kelas (PTK). PTK merupakan suatu pencermatan terhadap kegiatan yang sengaja dimunculkan, dan terjadi dalam sebuah kelas (Arikunto, 2010: 130). Penelitian ini dilaksanakan di SMP Negeri 2 Tawangsari.Tahap-tahap pelaksanaan kegiatan dilakukan selama kurang lebih lima bulan yaitu sejak bulan Juli sampai dengan Nopember 2018. Peneliti sebagai guru SMP Negeri 2 Tawangsari bertindak sebagai subjek yang melakukan tindakan kelas.Teman sejawat sesama guru mata pelajaran Matematika sebagai observer. Kepala Sekolah bertindak sebagai subjek yang membantu dalam perencanaan dan pengumpulan data. Subjek yang menerima tindakan adalah siswa kelas VIII F SMP Negeri 2 Tawangsari semester I tahun pelajaran 2018/ 2019 sebanyak 32 siswa.

Teknik pengumpulan data yang digunakan adalah: tes, observasi dan dokumentasi. Tes adalah serentetan pertanyaan atau latihan serta alat lain yang digunakan untuk mengukur keterampilan, pengetahuan inteligensi, kemampuan atau bakat yang dimiliki oleh individu dan kelompok (Arikunto, 2010 : 193). Tes digunakan adalah jenis tes hasil (achievement test) berupa kuis individu. Tes ini digunakan untuk mengukur pencapaian siswa setelah mempelajari materi. Hal ini dapat juga sebagai alat untuk mengetahui tingkat pemahaman siswa setelah mempelajari materi Koordinat Kartesius dengan menggunakan model pembelajaran aktif CRH. Tes yang digunakan adalah tes uraian yang jawabannya berupa isian berbentuk isian singkat atau uraian (Suprijono, 2013:138). Observasi atau pengamatan dilakukan guna memperoleh data yang akurat, dengan menggunakan lembar observasi. Lembar observasi digunakan untuk memonitor dan mengevaluasi setiap tindakan agar kegiatan observasi tidak terlepas dari konteks permasalahan dan tujuan penelitian.

Observasi yang digunakan adalah observasi sistematis, yaitu observasi yang dilakukan oleh pengamat dengan menggunakan pedoman sebagai instrumen pengamatan dan observasi non-sistematis yang dilakukan dengan tidak menggunakan instrumen pengamatan.Dokumentasi diperoleh dari hasil kuis siswa, lembar observasi, lembar wawancara, catatan lapangan, daftar siswa, dan foto-foto selama proses kegiatan belajar 
mengajar. Dokumentasi ini dimaksudkan adalah sebagai bukti-bukti konkret dari penelitian tindakan kelas tersebut.

Instrumen yang digunakan dalam penelitian berupa tes, lembar observasi dan lembar dokumentasi. Tes berbentuk tes tertulis maupun lisan yang dilakukan dalam post test dan kuis individu. Tes ini digunakan untuk mengetahui sejauh mana peningkatan prestasi belajar dengan penerapan model pembelajaran aktif CRH. Lembar Observasi, digunakan lembar observasi pelaksanaan pembelajaran aktif CRH. Lembar dokumentasi bertujuan untuk mengetahui data siswa selama kegiatan penelitian berlangsung.Lembar dokumentasi ini berupa, foto-foto kegiatan pembelajaran, daftar hadir kegiatan pembelajaran, daftar hadir, daftar nilai, kartu pasangan soal/jawaban dan sebagainya.

Indikator keberhasilan kinerja dalam penelitian ini adalah: (1) siswa dianggap mencapai ketuntasan belajar apabila mencapai lebih dari atau sama dengan KKM (KKM 71); (2) pembelajaran dianggap berhasil apabila tingkat ketuntasan kelas mencapai lebih dari atau sama dengan 88\%; dan (3) pembelajaran dianggap berhasil apabila siswa secara klasikal rata-rata mencapai lebih dari atau sama dengan 80.

\section{HASIL DAN PEMBAHASAN}

Deskripsi data hasil penelitian yang telah dilakukan di kelas VIII F SMP Negeri 2 Tawangsari adalah sebagai berikut. Berdasarkan observasi awal di kelas VIII F mata pelajaran Matematika dengan materi Koordinat Kartesius diperoleh data, dari 32 siswa yang mencapai nilai kriteria ketuntasan minimal (KKM) sebanyak 15 siswa (48,8\%), dengan nilai rata-rata kelas sebesar 65,8. Penelitian ini dilakukan dengan indikator kinerja nilai rata-rata tes siswa sekurang-kurangnya 80,0 dan banyak siswa dengan nilai di atas kriteria ketuntasan minimal (KKM) yaitu $\geq 71,0$ mencapai $\geq 85 \%$.

Berdasarkan pengalaman peneliti sebagai guru Matematika kelas VIII F, guru masih mendominasi kegiatan pembelajaran dan siswa cenderung tidak aktif. Salah satu solusi yang dikembangkan adalah penggunaan model pembelajaran yang baru yaitu dengan model pembelajaran aktif CRH. Dengan penggunaan model pembelajaran tersebut diharapkan akan menciptakan suasana belajar yang berbeda, bervariasi dan 
menyenangkan sehingga dapat menarik perhatian siswa, meningkatkan keaktifan siswa yang muara akhirnya meningkatkan prestasi belajar siswa.

Tindakan kelas siklus I dilaksanakan pada hari Selasa, 28 Agustus 2018 di SMP Negeri 2 Tawangsari kelas VIII F. Setelah langkah apersepsi dilanjutkan dengan penyampaian materi Koordinat Kartesius pada KD 2.1 memahami pengetahuan tentang titik, dan garis pada Koordinat Kartesius pada indikator mendeskripsikan pengertian titik, mengidentifikasi posisi titik, dan mengidentifikasi posisi garis dengan model pembelajaran aktif CRH.

Berdasarkan hasil evaluasi pada siklus I menunjukkan adanya peningkatan prestasi belajar siswa. Prestasi belajar siswa sebanyak 20 siswa mencapai nilai kriteria ketuntasan minimal (KKM) atau 62,5\%, rata-rata kelas naik menjadi 75,9. Berdasarkan pengamatan tersebut dapat diketahui bahwa proses pembelajaran pada siklus pertama belum berhasil maksimal dan belum mencapai indikator kinerja yang diharapkan. Peningkatan hasil, jika dibandingkan hasil prasiklus yang mencapai KKM sebanyak 15 siswa atau $48,8 \%$ setelah diberi tindakan penerapan siklus I, siswa yang mencapai KKM sebanyak 20 siswa atau $62,5 \%$.

Tabel 1. Perkembangan Siswa yang Mencapai KKM Sebelum Tindakan/ Prasiklus ke Siklus I

\begin{tabular}{clcc}
\hline No & \multicolumn{1}{c}{ Prestasi Siswa } & Prasiklus & Siklus I \\
\hline 1 & Rata-rata & 65,8 & 75,9 \\
2 & Siswa mencapai KKM & 15 & 20 \\
& & & \\
\hline
\end{tabular}

Dari tabel di atas dapat disimpulkan bahwa prestasi belajar Matematika materi Koordinat Kartesius pembelajaran aktif $\mathrm{CRH}$, pada pelaksanaan tindakan siklus I mengalami peningkatan. Sebelum dilakukan tindakan atau prasiklus, rata-rata prestasi belajar siswa sebesar 65,8 dan siswa yang mencapai KKM sebanyak 15 siswa, setelah tindakan siklus I, rata-rata prestasi belajar siswa menjadi 75,9 dan siswa yang mencapai KKM sebanyak 20 siswa sehingga meningkat 5 siswa. 
Setelah dievaluasi bersama dari pelaksanaan tindakan pada siklus I yang digunakan sebagai bagian pertimbangan perencanaan pembelajaran siklus berikutnya, dengan perencanaan perbaikan untuk mengatasi kekurangan dan kesalahan yang dilakukan pada siklus I. Tindakan kelas siklus II dilaksanakan pada hari Selasa, 4 September 2018 dengan materi Koordinat Kartesius pada KD 2.2 Posisi titik terhadap titik asal $(0,0)$ dan terhadap titik tertentu $(a, b)$ pada Koordinat Kartesius pada indikator posisi titik Koordinat Kartesius. Berdasarkan pembelajaran secara keseluruhan pada tindakan kelas siklus II menunjukan adanya peningkatan yang signifikan. Rata-rata nilai prestasi belajar siswa kelas VIII F naik menjadi 80,9 dan sebanyak 29 siswa $(90,6 \%)$ mencapai nilai kriteria ketuntasan minimal (KKM).

Tabel 2. Perkembangan Prestasi Belajar Siswa dari Siklus I ke Siklus II

\begin{tabular}{clcc}
\hline No & \multicolumn{1}{c}{ Prestasi Siswa } & Siklus I & Siklus II \\
\hline 1 & Rata-rata & 75,9 & 80,9 \\
2 & Siswa mencapai KKM & 20 & 29 \\
& & & \\
\hline
\end{tabular}

Berdasarkan data pada tabel di atas dapat disimpulkan bahwa prestasi belajar Matematika materi Koordinat Kartesius dengan menerapkan model pembelajaran aktif CRH, pada pelaksanaan tindakan siklus II mengalami peningkatan. Pada tindakan siklus I, rata-rata prestasi belajar siswa sebesar 75,9 dan siswa yang mencapai KKM sebanyak 20 siswa, setelah tindakan siklus II, rata-rata prestasi belajar siswa menjadi 80,9 dan siswa yang mencapai KKM sebanyak 29 siswa sehingga meningkat 9 siswa.Berdasarkan hasil tersebut dapat diketahui bahwa proses pembelajaran sampai dengan pada siklus II berjalan dengan baik dan telah memenuhi indikator kinerja yang diharapkan.

Pada siklus I dan II dengan penerapan tindakan menggunakan model pembelajaran aktif $\mathrm{CRH}$, siswa lebih antusias dengan perasaan senang dalam mengikuti kegiatan pembelajaran. Nilai rata-rata siswa sejak sebelum diadakan penelitian hingga setelah diadakan penenelitian sampai dengan siklus II, dapat dilihat pada tabel berikut: 
www.journal.univetbantara.ac.id/index.php/ijimm

\begin{tabular}{llccc}
\hline No & Prestasi Siswa & Prasiklus & Siklus I & Siklus II \\
\hline 1. & Rata-rata & 65,8 & 75,9 & 80,9 \\
2. & Siswa mencapai KKM & 15 & 20 & 29 \\
\hline
\end{tabular}

Dari tabel di atas dapat disimpulkan bahwa hasil belajar materi Koordinat Kartesius dengan menerapkan model pembelajaran aktif CRH, di setiap pelaksanaan tindakan, baik siklus I dan siklus II mengalami peningkatan, yaitu: siswa yang mencapai KKM sebelum dilakukan tindakan atau prasiklus 15 siswa, setelah tidakan siklus I sebanyak 20 siswa dan setelah tindakan siklus II sebanya 29 siswa, sehingga peningkatan kumulatif dari sebelum tindakan/prasiklus sampai dengan siklus II sebesar 14 siswa.

Tabel 4. Perkembangan Persentase Siswa Mencapai KKM Sebelum Tindakan/Prasiklus, Siklus I dan Siklus II

\begin{tabular}{clccc}
\hline No & Prestasi Siswa & Prasiklus & Siklus I & Siklus II \\
\hline 1 & Persentase Siswa & $48,8 \%$ & $62,5 \%$ & $90,6 \%$ \\
& Mencapai KKM & & &
\end{tabular}

Dari tabel di atas dapat disimpulkan bahwa prestasi belajar Matematika materi Koordinat Kartesius dengan menerapkan model pembelajaran aktif $\mathrm{CRH}$, di setiap pelaksanaan tindakan mengalami peningkatan, yaitu: persentase siswa yang mencapai KKM sebelum dilakukan tindakan atau prasiklus 48,8\%, setelah tidakan siklus I sebanyak 62,5\% dan setelah tindakan siklus II sebanya 90,6\%.

Tabel 5. Perkembangan Nilai Rata-rata Kelas Sebelum Tindakan/Prasiklus, Siklus I dan Siklus II

\begin{tabular}{ccccc}
\hline No & Prestasi Siswa & Prasiklus & Siklus I & Siklus II \\
\hline 1 & Nilai rata-rata & 65,8 & 75,9 & 80,9
\end{tabular}

Berdasarkan data tabel di atas dapat disimpulkan bahwa prestasi belajar materi Koordinat Kartesius dengan menerapkan model pembelajaran aktif CRH, di setiap pelaksanaan tindakan mengalami peningkatan, yaitu: nilai rata-rata kelas sebelum dilakukan tindakan atau prasiklus adalah 65,8, setelah tidakan siklus I adalah 75,9 dan setelah tindakan siklus II adalah 80,9 sehingga dari kondisi awal sebelum tindakan/prasiklus sampai dengan tidakan pada siklus II terjadi peningkatan. Dari uraian 
di atas dapat disimpulkan bahwa model pembelajaran aktif CRH dapat meningkatkan prestasi belajar materi Koordinat Kartesius siswa kelas VIII F SMP Negeri 2 Tawangsari semester I tahun pelajaran 2018/ 2019.

Pada penelitian kondisi awal diperoleh data yang dapat ditabulasikan sebagai berikut:

Tabel 6. Nilai Hasil Pengamatan awal

\begin{tabular}{cc}
\hline Nilai & Test Individual \\
\hline Terendah & 60 \\
Tertinggi & 85 \\
Jumlah & 2106 \\
Rata-rata & 65,8 \\
Persentase ketuntasan & $48,8 \%$ \\
\hline
\end{tabular}

Pada siklus I diperoleh data yang dapat ditabulasikan sebagai berikut:

Tabel 7. Nilai Hasil Pengamatan Siklus I

\begin{tabular}{cc}
\hline Nilai & Test Individual \\
\hline Terendah & 65 \\
Tertinggi & 89 \\
Jumlah & 2655 \\
Rata-rata & 75,9 \\
Persentase ketuntasan & $62,5 \%$ \\
\hline
\end{tabular}

Pada siklus II diperoleh data yang dapat ditabulasikan seperti berikut:

Tabel 8. Nilai Hasil Pengamatan Siklus II

\begin{tabular}{cc}
\hline Nilai & Test Individual \\
\hline Terendah & 69 \\
Tertinggi & 97 \\
Jumlah & 2589 \\
Rata-rata & 80,9 \\
Persentase ketuntasan & $90,6 \%$ \\
\hline
\end{tabular}

Tabel 9. Profil Kelas Sebelum dan Sesudah Tindakan Penelitian

\begin{tabular}{lllll}
\hline No & Hasil Siswa & Kondisi Awal & Siklus I & Siklus II \\
\hline 2 & Nilai rata-rata & 65,8 & 75,9 & 80,9 \\
3 & Siswa yang tuntas KKM & 15 siswa & 20 siswa & 29 siswa \\
& & $(48,8 \%)$ & $(62,5 \%)$ & $(90,6 \%)$ \\
\hline
\end{tabular}




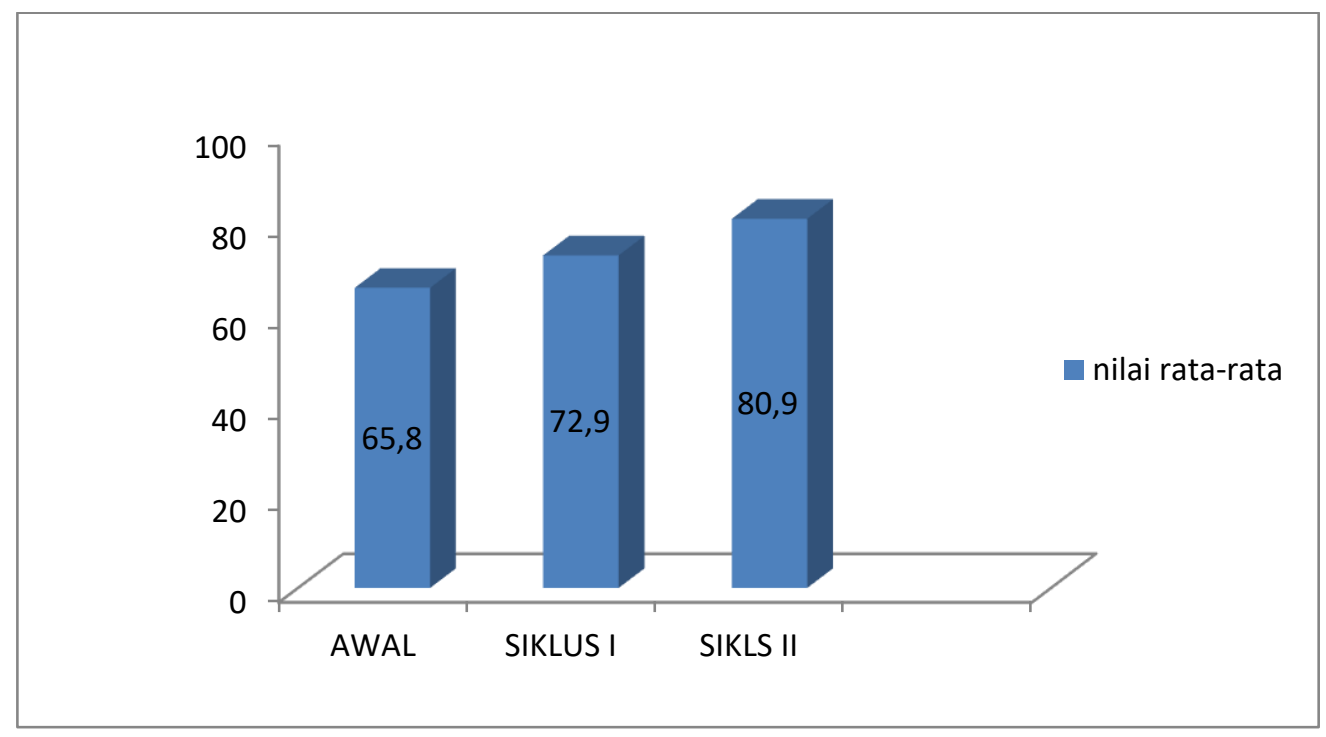

Gambar 1. Rata-rata Prestasi Belajar Siswa pada Kondisi Awal, Siklus I, dan Siklus II

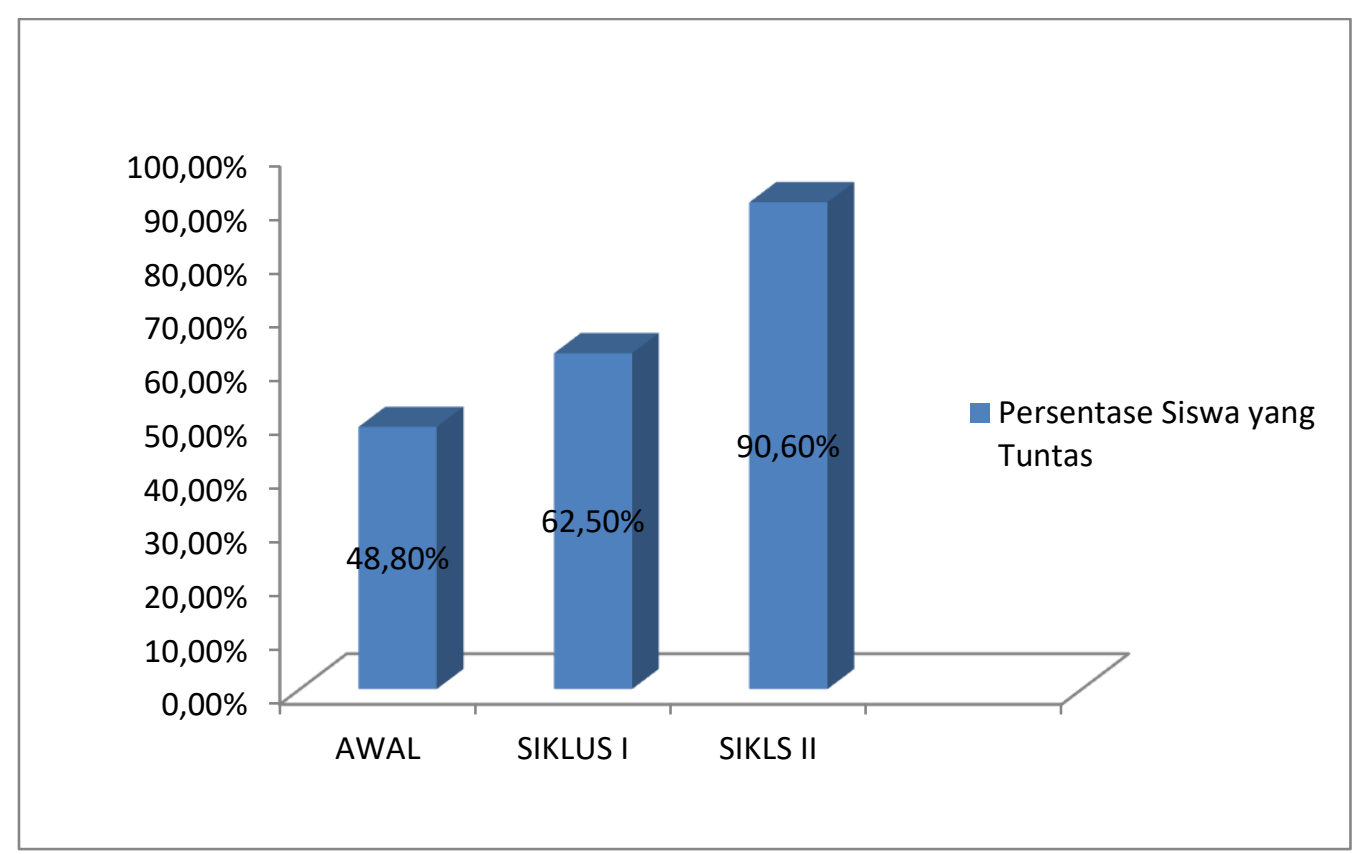

Gambar 2. Persentase Ketuntasan Siswa pada Kondisi Awal, Siklus I, dan Siklus II

Berdasarkan grafik di atas dapat ditunjukkan bahwa prestasi belajar siswa dengan menerapkan pembelajaran model aktif tipe CRH di setiap putaran mengalami peningkatan, yaitu: (1) Sebelum dilakukan tindakan penelitian kelas nilai rata-rata hasil belajar siswa adalah 65,8 dengan presentase prestasi belajar siswa hanya 48,8\%, Setelah dilakukan tindakan pada siklus I nilai rata-rata prestasi belajar siswa mengalami peningkatan yaitu 72,9 dengan presentase ketuntasan $62,5 \%$, tetapi belum mencapai 
indikator yang diharapkan; (3) Pada siklus II nilai rata-rata prestasi belajar siswa meningkat yaitu menjadi 80,9 dengan presentase ketuntasan sebesar 90,6\% dan sudah mencapai indikator yang diharapkan maka penelitian tindakan kelas ini sudah berhasil.

Rata-rata prestasi belajar siswa pada kondisi awal 65,8 dengan persentase ketuntasan belajar siswa sebesar 48,8\%, pada siklus II naik menjadi 80,9 $\geq 80,0$ (indikator kinerja) dengan presentase ketuntasan belajar siswa sebesar 90,6 $\geq 85 \%$ (indikator kinerja). Jadi, indikator kinerja sudah tercapai sehingga tidak dilanjutkan ke siklus berikutnya.

\section{SIMPULAN DAN SARAN}

Berdasarkan hasil penelitian dapat disimpulkan bahwa: "Model pembelajaran aktif CRH dapat meningkatkan prestasi belajar Matematika siswa kelas VIII F semester I SMP Negeri 2 Tawangsari tahun pelajaran 2018/ 2019. Hasil penelitian ini menunjukkan adanya peningkatan pada prestasi belajar Matematika siswa. Hal ini dapat dilihat dari nilai rata-rata prestasi belajar Matematika siswa juga mengalami peningkatan yaitu sebelum tindakan sebesar 65,8, pada siklus I sebesar 72,9 dan pada siklus II sebesar 80,9. Selain itu, persentase ketuntasan belajar siswa, yaitu sebelum tindakan sebesar $48,8 \%$, pada siklus I sebesar $62,5 \%$ dan pada siklus II sebesar $90,6 \%$.

Penelitian Tindakan Kelas (PTK) yang dilaksanakan di SMP Negeri 2 Tawangsari ini sudah berjalan dengan cukup baik dan hasil yang baik pula. Namun masih banyak hal yang perlu diperbaiki. Oleh karena itu, peneliti memberikan beberapa saran.Dalam mengikuti pembelajaran Matematika disarankan siswa dapat aktif dalam beraktifitas dikelas baik saat kegiatan belajar mengajar (KBM) ataupun saat berdiskusi kelompok. Sehingga dapat meningkatkan pemahaman materi yang sedang diajarkan dan dapat meningkatkan prestasi belajar siswa yang optimal sehingga dapat mencapai melebihi KKM.

Guru Matematika hendaknya dapat menumbuh kembangkan kreativitas dalam menjalankan profesinya sebagai fasilitator dan motivator dalam menyampaikan pembelajaran secara kreaktif dan inovatif pada siswa dalam penyampaian materi, sehingga siswa dapat menerima dan memahami materi yang diajarkan dengan baik. 
Sekolah disarankan mengadakan rapat uintuk membahas model pembelajaran yang inovatif dan menyenangkan seperti model pembelajaran aktif Course Review Horay $(C R H)$ untuk diterapkan dalam pembelajaran. Agar lebih meningkatkan keaktifan siswa dan prestasi belajar siswa dalam belajar Matematika.

Penelitian Tindakan Kelas (PTK) ini diharapkan akan membawa dampak positif terhadap perkembangan sekolah yang nampak pada peningkatan prestasi belajar siswa sehingga dapat meningkatkan prestasi dan kualitas sekolah.

\section{DAFTAR REFERENSI}

Arikunto, Suharsimi.2006. Prosedur Penelitian. Jakarta: RinekaCipta

Sardiman A.M. 2010. Interaksi dan Motivasi Belajar Mengajar. Jakarta: PT Raja Grafindo Persada.

Sudiyana. 2012. Penelitian Tindakan Kelas. Yogyakarta: Cakra books dan Bradelvi.

Suprijono, Agus. 2013. Cooperative Learning Teori dan Aplikasinya. Yogyakarta: Pustaka Pelajar.

Warsono,Hariyanto. 2013. Pembelajaran Aktif Teori dan Assesmen. Bandung: PT Remaja Rosdakarya Offset. 